\title{
Reinscribing History: Mendez et al. v. Westminster et al. from the Standpoint of Mexican Origin Women
}

\author{
Nadine Bermudez
}

The main plaintiffs named in Mendez et al. v. Westminster School District et al. were Gonzalo Mendez, William Guzman, Lorenzo Ramirez, Frank Palomino, Tomas Estrada, and their children. As the children's fathers and "next of friend," these men were identified as the children's legal guardians and therefore named lead plaintiffs in the Mendez case by the court, legal counsel, and the plaintiffs themselves. Not readily identified in the Mendez case, or subsequential writings about it, however, were the children's mothers: Felicitas Mendez, Virginia Guzman, Josefina Ramirez, Irene Palomino, and Maria Luisa Estrada.

The absence of these women and others from official accounts surrounding the case comes as no surprise. At a time in history when "a woman's place was in the home" and men were regarded as head of the house, the male centeredness of the Mendez case could be attributed to a patriarchal legal system, perceptions of women within the Mexican culture and the greater society, and/ or the manner in which history is traditionally constructed and told. But the erasing of these women from historical memory in no way diminishes their significance to the case or the overall battle for desegregation. Regardless of these women's "official" status, they and others made important contributions to the Mendez case and the battle for racial equality.

The intention of this paper is to reclaim a history long ignored. It seeks to tell the story of Mendez v. Westminster from the standpoint of Mexican origin 
women, ${ }^{2}$ as told and remembered by those who lived it. Important to this telling of the Mendez case is an understanding of the methods and theories used to identify the many women involved in desegregation efforts and the manner in which gender intersected with race to inform their agency.

\section{Approaching an Alternative Telling of the Mendez Case}

At the cornerstone of this study stand the testimonies of those involved in grassroots efforts to desegregate the schools. In addition to interviewing key plaintiffs named in the lawsuit, including representatives of the five leading families (Mendez, Guzman, Palomino, Ramirez, and Estrada), I also interviewed former students of the Mexican schools and a host of community members. I identified these participants in part from the legal documents, most notably the court transcripts. More significant to this study and my efforts to determine the contributions of Mexican origin women to the case, however, is an investigation into the knowledge and experiences of participants not readily identified in the legal documents. These participants were largely identified by other participants involved in this study. For the purposes of this investigation, I make a distinction between those whose actions were officially recorded and those whose actions were not. Because most accounts of the Mendez case rely largely on court records, they tend to offer a limited perspective of the people and events surrounding it. In contrast, a study of those who participated but had little, if any, involvement in the legal proceedings provided a window for new information to emerge. I created this window through my familial ties to the Mendez case.

As long-time residents of the Westminster community, the name Bermudez is well rooted in its history. Many attended the Mexican schools in question and actively engaged in desegregation efforts. Evidence of this is located in the stories shared by research participants and the pages of documents making up the Mendez case. For example, the signatures of several of my relatives, including my grandparents, appeared on the petition that was circulated among residents in the Mexican American community and later forwarded to the Westminster School District [Figure 1].

Documents such as this helped to shape my understanding of the Mendez case. In a preliminary study I conducted, I interviewed several families whose signatures appeared on this petition but, subsequently, was unable to locate their names in the legal documents. This raised my curiosity about the grassroots efforts of those involved and the events that would ultimately amount to a class action lawsuit. Moreover, I realized that, as a Bermudez, my family surname afforded me access to data that might not otherwise be available.

From the onset of my investigation, I was introduced to a host of people from across Orange County. Some were directly involved in the desegregation battle, while others had family members or friends who participated. They, in turn, introduced me to others, and they others. With each new encounter, I 


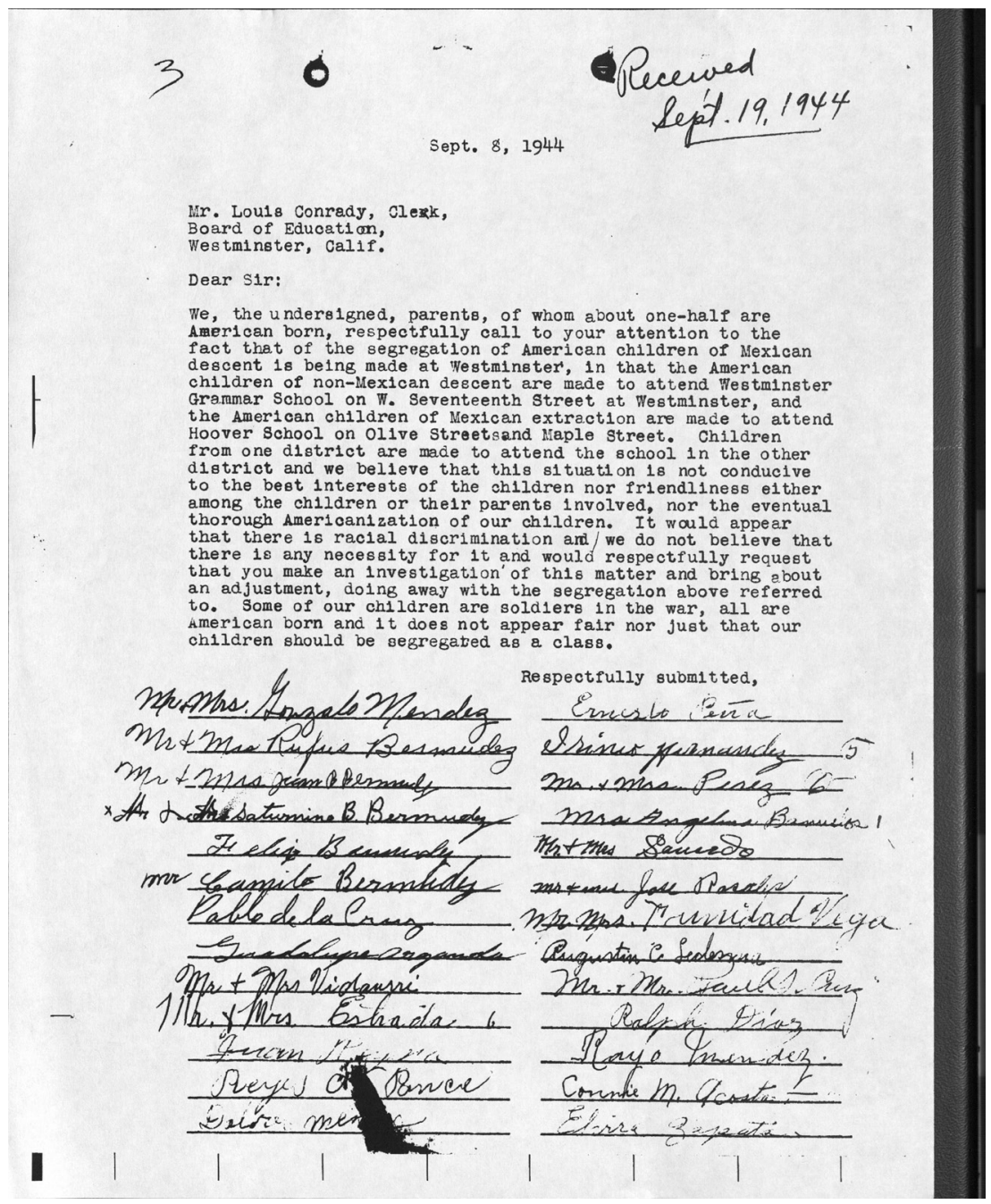

Figure 1: Petition sent to the Westminster School District by members of the Mexican American community requesting an investigation into the matter of school segregation. Westminster, California, September 8, 1944. Frank Mt. Pleasant Library of Special Collections and Archives, Chapman University, California.

became privy to new facets of the Mendez case, many that remained obscure in the literature I reviewed. For example, it was my aunt, Terri Salinas, and a former student of the Hoover (Mexican) School in Westminster, who arranged for me to meet a distant cousin of mine who knew of his mother's involvement in the Mendez case. During the meeting, I learned of my great aunt Rosalia Bermudez's participation in early stages of the desegregation struggle and, sub- 
sequently, located her contributions in the existing documents. My Aunt Terri also introduced me to Sylvia Mendez, her childhood friend and cousin by marriage. As one of the lead plaintiffs named in the lawsuit, Sylvia shared with me her memories of the case and her family's efforts to desegregate the schools. Her participation in this study, along with other former students of the Mexican schools, provided a voice for those most affected by school segregation: the students themselves.

In another example, I was informed by a distant relative, who also lived in Westminster and attended the Hoover (Mexican) School, about a group of women in her neighborhood who preferred separate schools for their children. She recalled as a child attending meetings with her aunt and some of the other mothers from her neighborhood because, as she described it, "we wanted a school of our own . . . in our community". ${ }^{3}$ According to this participant, these women opted for segregated schools out of concern for the children's safety. Although such findings may not be new to studies regarding de jure segregation, ${ }^{4}$ they are new to studies regarding the Mendez case. In my opinion, such findings were worthy of further investigation, and in time they reshaped my understanding of the case.

Privy to such information, I began to wonder about the many people involved in the lawsuit and their varied contributions to the desegregation struggle. What of their stories, thoughts, and concerns? What knowledge and experiences might they possess? And what might their telling of the Mendez case reveal? I further considered the genesis of the case and how a community-based struggle would come to emerge as a class action lawsuit. What events might have transpired, and who participated and why? Consequently, as I delved deeper into my research and began to peel back its many layers, it became apparent to me that a backstory to the Mendez case existed, one that involved the agency of Mexican origin women. Their experiences guided my research and became the focus of my investigation.

As indicated, this telling of the Mendez case was purposely shaped by those who lived it. Driving the research were many people personally involved in the desegregation battle, including those who were segregated, those who resisted, and those who filed suit. This is an important distinction to make considering the magnitude of the Mendez case. Though it began as a community struggle, with the help and leadership of five key families (i.e., Mendez, Guzman, Palomino, Estrada, and Ramirez), it eventually emerged as a class action lawsuit before the Ninth Circuit Court of Appeals. Representative of 5,000 people, and four different school districts (i.e., Westminster, Santa Ana, El Modena, and Garden Grove), the case of Mendez et al. v. Westminster et al. essentially spanned a seven-year period. In an effort to determine the people and actions responsible for its manifestation, I constructed a working timeframe of the events that would come to define it [Figure 2]. Such an approach allowed key actors to emerge at various stages of the desegregation battle. This approach further 


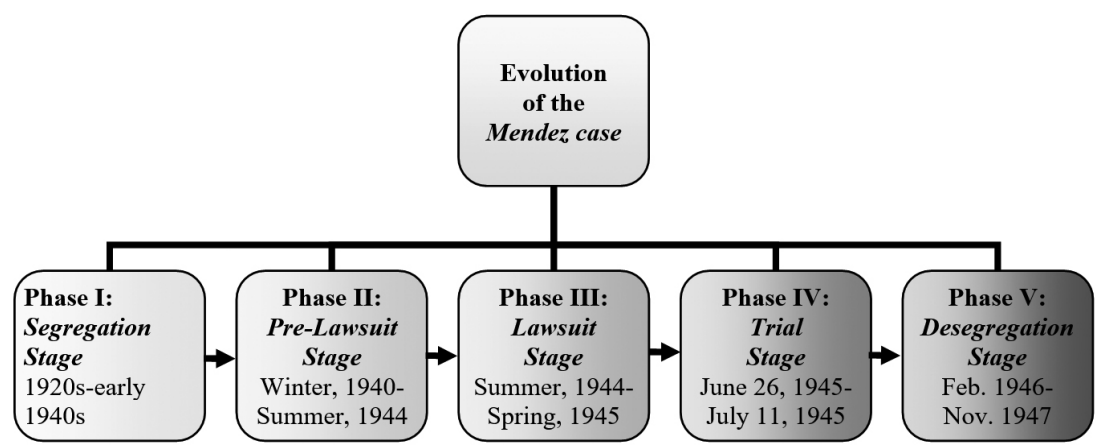

Figure 2: Depicts the Mendez case from the early stages of segregation to the later stages of desegregation.

underscored the significance of its grassroots origin, which ultimately cast a light on the contributions of Mexican origin women.

Further informing this study were the research methods employed. To get at the stories of those typically ignored by conventional research, I utilized methodologies that considered the experiential knowledge participants possessed. Those that proved most useful were Participatory Action Research, which positioned participants to take an active role in the research process; Critical Race Theory, which provided a lens from which to consider perceptions of race as they intersected with gender; and Counterstory-telling, which allowed the voices of participants to be heard. The combination of these methods provided a forum for new information to emerge. ${ }^{5}$ This is particularly true of Counterstory-telling. With the stories of women virtually ignored in popular narratives surrounding the case, Counterstory-telling provided a space to consider "those people whose experiences are not often told." Providing a conceptual framework from which to analyze the data was Chicana feminist theory. By shifting women "from the margins to the center" of my study, ${ }^{7}$ I was better able to determine the implications of gender to the case. The following is a brief discussion of Chicana Feminist Theory as deemed necessary to this telling of Mendez v. Westminster.

\section{The Framing of the Mendez Case from a Chicana Feminist Perspective}

One of the most empowering things we can do is articulate the mechanisms of silencing: the discourse of silencing, the discourse against giving voice, the discourse against resistance. $^{8}$ 
For the women involved in the Mendez case, the "mechanisms of silencing" took the form of that considered "official," and thus deemed worthy of knowing and repeating. Lost to the "mechanisms," Cordova forewarns, are the contributions of women to this historical event. ${ }^{9}$ Though some may argue that the Mendez case has received a great deal of attention in recent years and thus is finally getting its just due, ${ }^{10}$ missing from such acknowledgments is a thorough account of women's participation in this landmark case. More often than not, the inclusion of women in stories about the Mendez case has tended to be tokenized or viewed as secondary. This contention may be best exemplified in the typical framing of Felicitas Mendez's contributions to the case. ${ }^{11}$

As the wife of Gonzalo Mendez, a key plaintiff named in the lawsuit, Felicitas's participation in the case is often referenced in terms of her willingness to run the family farm so that her husband could dedicate more time to the lawsuit. ${ }^{12}$ By all accounts, Felicitas successfully took on the role of la patrona (the boss), which allowed her husband to pursue the lawsuit more diligently, thus allowing legal proceedings to move forward more quickly. However, the propensity to frame Felicitas's actions in relationship to those of her husband minimizes her involvement in the case and/or casts her in a supportive role, what Chicana historian Emma Perez describes as "a backdrop to men's social and political activities. ${ }^{\prime 13}$ With few exceptions, ${ }^{14}$ most accounts of the Mendez case fail to mention that in addition to running the farm, she also testified in court, participated in parent meetings, met with school officials, and helped to organize the community. Such narrow accounts not only in regard to the Mendez case but to Chicano accounts in general serve to limit our understanding of the past and perpetuate the marginalization of those silenced by such tellings. ${ }^{15}$

For Felicitas Mendez and the countless other women involved in desegregation efforts, the genderization of the case has allowed their stories to be rendered irrelevant and thus invisible. Yet, it is important to remember that while their stories have gone ignored, their omission - intentional or not - never truly rendered them invisible or irrelevant. On the contrary, whether they are acknowledged by those who manufacture history is immaterial to the fact that these stories exist, and it is their sheer existence that stands as testament to their significance. They offer us insight into the human spirit and the agency of those who dare to tell.

For Chicana scholars, feminists, and the like (myself included), it is our struggle to make sense of the world and our place in it that allows such stories to emerge. In our effort to locate the voices of those long silenced, we look to create new ways of seeing, thinking, and speaking about women of color and, in the process, shift paradigms and create new discourses. Those most fitting to a study of Mendez are those that are inclusive of race, class, and gender and mindful of the Chicana experience. Renowned scholar Cherrie Moraga defined such experiences as "theories in the flesh." In her much acclaimed book This Bridge Called My Back: Writings by Radical Women of Color, Moraga described "theories in the flesh" as spaces "where the physical realities of our 
lives - our skin color, the land or concrete we grew up on, our sexual longings-all fuse to create a politic born out of necessity." She further wrote:

[W]e attempt to bridge the contradictions in our experience.

We are the colored in a White feminist movement.

We are the feminists among the people of our culture.

We are often the lesbians among the straight.

We do this bridging by naming ourselves and telling our stories in our own words. ${ }^{16}$

For the many women involved in the Mendez case, the contradictions were plentiful. They were the brown among the white, they were the Mexicans among the Americans, they were the women in a patriarchal society, and they were the citizens in a segregated nation. For these women, the "politics born out of necessity" emerged from their status as working-class women of color in a nation stratified by race, class, and gender. ${ }^{17}$ And in their effort to "bridge the contradictions" that constrained their children, these women named themselves. As women, mothers, wives, and daughters, as Mexicans, Americans, patriots, and citizens, they unequivocally named themselves - and, in so doing, they found their voice and "told their stories in their own words." It is this naming that informed their resistance, and their telling that reinscribes their place in history.

\section{The Contributions of Women of Mexican Ancestry to the Mendez, Case}

A gender analysis of the Mendez case suggests that the participation of women of Mexican ancestry was largely informed by two key factors: their identification as mothers, particularly within the Chicano/Mexican community, and their identification as Americans, particularly at the height of World War II. $^{18}$

Beginning with the Second World War, plaintiffs involved in the Mendez case framed many of their arguments in their status as Americans and their unfaltering support for their country during wartime. For example, in the aforementioned petition, parents asserted, "Some of our children are soldiers in the war, all are American born and it does not appear fair nor just that our children should be segregated as a class." ${ }^{19}$ As indicated, these parents grounded their argument in their democratic beliefs and justified them with their patriotic actions. This strategy is evident in the pages of documents surrounding the Mendez case. Many had children fighting overseas, sacrificed for the good of their country, and actively supported the war on the home front; Mexican American women proved no exception. For example, Virginia Guzman, the wife of William Guzman, a lead plaintiff named in the lawsuit, did her part for the war by volunteering for REACT, a local organization dedicated to protecting the Unit- 


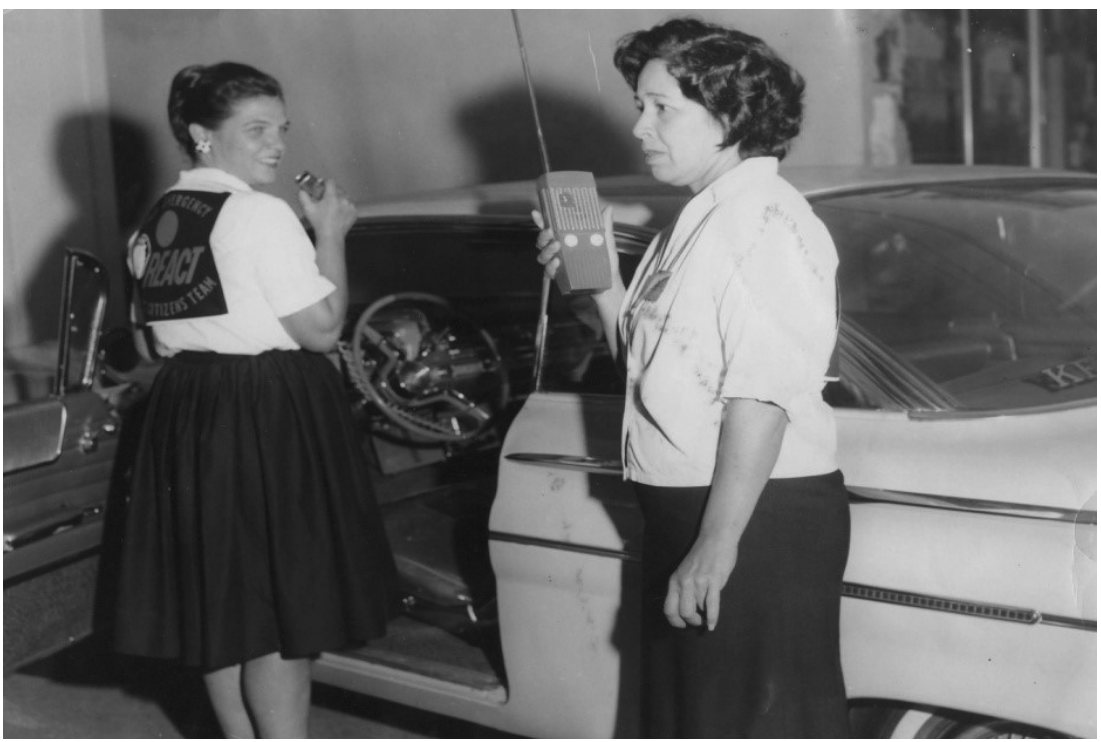

Figure 3: Virginia Guzman (right) with a co-member of REACT, 1943. Courtesy of Virginia Guzman and the Guzman family.

ed States during such turbulent times [Figure 3]. Her responsibilities included aiding in the distribution of health care and providing communication services to the public. In an interview for this study, Virginia stated, "When they first came up with that injection [for polio], they used to have them in the schools. So we used to help them by radio, communication by radio."20

Virginia Guzman's volunteer efforts reflected her sense of civic duty and strong feelings of patriotism, as well as her level of social consciousness. Recollecting her and her husband's involvement in REACT, Virginia stated, "We were the only Mexicanos in that group. Eremos los únicos Mexicanos [We were the only Mexicans]." In being "the only Mexicanos," Virginia pondered her status as an American and notions of race in this country. She recalled, "I couldn't understand why there was separation. We were born here. Por qué estabán segregando a los Mexicanos?" (Why were the Mexicans segregated?)

Many Mexican Americans during World War II shared the perplexity expressed by Virginia Guzman. Based on Du Bois's theory of "double consciousness," ${ }^{21}$ Griswold del Castillo described in his book World War II and the Mexican American Civil Rights the difficulties of "considering yourself a patriotic American while experiencing second-class citizenship."22 Although many Mexican Americans had served in the war and sacrificed for the good of their country, they were, in del Castillo's words, "treated as foreigners and outsiders who did not belong." ${ }^{23}$ The incongruity of "being a loyal American while being treated as an outcast" would cause many like Virginia Guzman to question their ambiguous status as Americans. ${ }^{24}$ She said: 
I didn't understand. There was segregation. ... They wouldn't serve you in all the restaurants, in the theatres, $y$ todo estaba separado [everything was separate]. I felt what was going on in the schools [segregation] was going on in other things, too.

Similar to Virginia Guzman, others were likewise conflicted by their in-between status as Americans of Mexican ancestry and the racial discrepancies accentuated by the war. For example, Felicitas Fuentes, one of the ten women who testified for the plaintiffs, expressed to the court her thoughts about World War II and its relationship to the segregation of her son. In her testimony before the court, Felicitas Fuentes relayed a conversation she had with the superintendent of the Santa Ana School District, in which she reasoned that "if our Mexican people were dirty," as the superintendent told her, then why "did they [Americans] have all our boys fighting overseas ... why didn't they bring them back and let us have them home?"25 Asserting that she was an American citizen, she further contended that, "if they weren't qualified to have an education as all the American people," adding that she too was "an American citizen" and wondering "if Joe [her oldest son] wasn't qualified . . . why didn't they let me have him and not take him overseas, as he is right now?" Felicitas makes a compelling argument. If indeed her son and others were "American enough" to fight overseas, then why were they not "American enough" to receive the same rights and privileges as other Americans, including the right to a quality education?

In response to the discrimination she and her children experienced, Felicitas Fuentes's understanding of the war compelled her to engage in a form of resistance that struck at the core of American ideals. As explained by Chicano historian Rudy Acuña, "The shocks caused by the war exposed contradictions in the American paradigm of equal treatment and opportunity." ${ }^{26}$ Armed with American ideals and democratic principles, women such as Felicitas Fuentes and Virginia Guzman forced the courts to weigh in Mendez their ambiguous status as people of color in a nation rooted in notions of race. Thus, on trial at the height of World War II was more than the segregation of Mexican children, but the very notion of democracy itself, as evident in the sworn testimony of Felicitas Mendez:

We always tell our children they are Americans, and I feel I am American myself, and so is my husband, and we thought that they shouldn't be segregated like that. They shouldn't be treated the way they are. So we thought we were doing the right thing ... just asking for the right thing, to put our children together with the rest of the children there [at the 17th Street (White) School]..$^{27}$

Once again, these women posited their identification as Americans as justification for racial equality. Felicitas Mendez made it clear in her testimony that she 
and her family were Americans, and thus entitled to the same treatment as other Americans.

It is obvious from the statements of these women that World War II forced a reconfiguration of race relations in the United States. Over time, these shifts would inspire generations of Mexican Americans and lay the groundwork for changes to come. Griswold del Castillo succinctly explained that "these war time women were the mothers of those who participated in the women's movement of the 1960s and 1970s and thus were their role models. ${ }^{.28}$ Indeed, to truly appreciate the significance of their actions in 1940s wartime America, one must consider the sociopolitical context in which they occurred. That is to say, the women involved in the Mendez case never identified as activists, feminists, Chicanas, or nationalists, but instead as Americans, mothers, sisters, and citizens. They believed in the fairness and goodness of America and fought to protect it from enemies afar. They were motivated by a love for their family and a love for their country. Thus, when Mexican origin children were denied their constitutional rights, they asked why. But unlike subsequent generations, they did so within the context of the Second World War. The women of Mendez never "walked out" or "sat in," nor did they rally, demonstrate, or march. They did, however, organize and resist. In their efforts to protect their children from institutionalized racism and ensure the best education possible for them, they engaged in a type of resistance that challenged social conventionality on one hand, yet adhered to it on the other. Measured by contemporary standards, such resistance may appear moderate or reserved, but in fact proved quite contentious in its day.

Long before the 1960 and 1970s Civil Rights Movement, Feminist Movement, and Chicano Movement, the women involved in the desegregation battle engaged in action that could be construed as radical, defiant, and even unAmerican. Not surprisingly, such notions are located in the sworn testimony of defendants named in the lawsuit, including their legal counsel, and even among some in the Mexican American community. In fact, my grandmother, Ysaura Bermudez, a longtime resident of Westminster, at age eighty-five, recalled those involved in the Mendez case being labeled as metiches (nosy). ${ }^{29}$

My grandma's memories of such acts as meddlesome are confirmed by del Castillo, when he described how "fighting for equal privileges constituted a social error, a simple case of bad manners - pushing yourself in where you weren't wanted." ${ }^{30}$ The perception of Mexican American women's actions as nosy, adverse, and, by some accounts, "undemocratic" 31 makes for a particularly interesting discussion regarding the correlation between those involved in the Mendez case and their identity as Americans. It further serves to inform questions regarding the type of actions engaged in by the women identified in this study.

In a number of interviews I conducted, research participants recalled the unwillingness of some in the Mexican American community to become involved in the Mendez case. When asked to explain such reluctance, participants 
attributed it to various factors, such as fear, intimidation, ignorance, and loyalty. For example, Virginia Guzman recalled her neighbors' aversion to participating in the Mendez case out of loyalty to the local school principal:

When we asked people to help us, to get involved in this case, they said "Oh, no. We cannot get involved in this because the principal, Mrs. Gilbert ... she helps the Mexican people out. ... She's so good. She helps us."

Other participants related such reluctance to one's personal circumstances, such as a person's immigrant or financial status, personality traits and/or emotional state, including feelings of complacency, timidity, or apathy. ${ }^{32}$ In a 2005 interview for this study, Josefina Ramirez, wife of Lorenzo Ramirez, a lead plaintiff named in the lawsuit, relayed her thoughts about the hesitation of some to further extend their support to her husband and his pursuit of legal justice:

\begin{abstract}
Muchos señores que le ayudaban a él fueron a pedir permiso que los dejaran salir del trabajo y les dijeron que "No." Que si salían del trabajo los iban a correr. Por eso fue que ya no quisieron ayudarle..$^{33}$ (Many men that were helping him went to ask for permission so that they'd be allowed to leave work, and they were told, "No," that if they left work, they were going to get fired. That's why they didn't want to help him anymore. $)^{34}$
\end{abstract}

A study of the reluctance on the part of some to get involved in the Mendez case proved quite telling and served to inform questions regarding how and why women responded to school segregation. Many, therefore, hesitated to get involved in the Mendez case for various reasons. Whatever explanation participants rendered - be it one's social, political, or emotional status - it is important to note that the underlying factor seemed to be rooted in their identity as Americans and the uncertainty this seemed to generate. Virginia Guzman, for example, expressed the fear she observed from those in her community regarding a petition she and her husband circulated in support of the Mendez case. Remembering the apprehension of some of her neighbors to sign, Virginia stated, "They were afraid that they [the authorities] were gonna do something to them. . . They were timid. They didn't speak. They just said, no, no, no." The idea that "they were gonna do something to them" reflects not only the level of contention surrounding the Mendez case, especially at the height of World War II, but perhaps also deep-seated notions of race in the United States. Afraid for their children, or perhaps having internalized their second-class status as Americans, some may have accepted the segregation of Mexican children as normal and, inadvertently, their relegated place in society. In so doing, these 
parents made the calculated decision not to participate in the Mendez case out of fear for their children's well-being.

In her study of black women, Patricia Hill Collins posited that black mothers sometimes teach their children to "fit into systems of oppression" as a tactical means of helping them survive. ${ }^{35}$ Based on their "unique angle of vision," Collins asserted that black mothers view such tactics as essential to the physical survival of their children. A similar strategy may have been employed by these parents. In an effort to protect their children from the racist practices of a discriminatory school system, they may have opted not to get involved in legal proceedings. Hence, what appears to be complacency may in fact be a form of resistance; in other words, the calculated decision not to act in itself may constitute an act. However, Collins warns against the dangers of teaching young people to be "willing participants in their own subordination." ${ }^{36}$ Collins wrote, "Mothers may have ensured their daughters' physical survival, but at the high cost of their emotional destruction." ${ }^{37}$ Collins went on to describe the delicate balance African American mothers face in trying to ensure their children's survival, while simultaneously "instilling values that will encourage their children to reject their 'place' and strive for more." ${ }^{38}$ Collins identified this paradox as "visionary pragmatism, that is, the idea that Black children must remain "visionary about what is possible, yet pragmatic about what it might take to get there." ${ }^{39}$ If Mexican origin parents were cognizant of the risks involved in participating in the Mendez case and then made the calculated decision not to participate to ensure their children's survival, this could be construed as "visionary pragmatism." However, if parents responded out of fear or compliance, with no vision of transcending their children's lives, this would most likely meet the criteria of conformist behavior. ${ }^{40}$ Whatever their reasons, many in the Mexican American community were wary about the case and the risks it posed to their children's safety.

Another explanation regarding the reluctance on the part of some parents to participate in desegregation efforts is that they may have actually preferred separate schools for their children. As previously mentioned, one former student of the Hoover (Mexican) school recalled how, in the 1930s, her aunt and some of the other "ladies from the community" requested that the Westminster School District build a separate school in their community. In a preliminary interview conducted for this study, this long-time resident of Westminster recollected the concerns these women expressed for the safety of their children and why they preferred a school in their own neighborhood. In regard to their children's safety, several participants made reference to the location of the 17th Street (White) School, which required students to cross a busy intersection and the railroad tracks virtually dividing Mexicans and whites. Others attributed it to a mistrust some Mexicans had for whites. As confirmed by Terri Salinas, "Around the block there was a family we grew up with. They weren't for it. They didn't want to integrate. . . . They didn't trust White people." Whatever their reasons, some in the community were reluctant to become involved in the 
Mendez case. But whether they supported school integration or not, the data are conclusive in one respect: they acted in what they perceived to be the best interest of their children.

The debate over racially separate or integrated schools raises questions about what motivated Mexican American women to act. In his book Silent Covenants: Brown v. Board of Education and the Unfulfilled Hopes for Racial Reform, Derrick Bell posited that desegregation efforts in the landmark desegregation case Brown v. Board of Education of Topeka (1954) had less to do with the practice of segregation and more to do with ideals of equality. Referencing other legal cases, ${ }^{41}$ Bell wrote that "while Brown was fashioned on the theory that equal education and integration were one and the same thing, the goal was not integration but equal educational opportunity". ${ }^{42}$ The same logic is applicable to a study of the Mendez case. Long before they ever filed suit, the mothers of Mexican origin students worked to get their children out of the Mexican schools and into the white schools. This is evident in the legal documents. Riddled throughout the court transcripts are numerous references to mothers requesting school transfers for their children. In accordance with Bell's theory of Brown, the question is so raised in Mendez: did these mothers act because they favored the integration of their children with whites, or because they were unsatisfied with the quality of education at the Mexican schools? The data point to the latter.

Based on court transcripts, Felicitas Fuentes tried to get her son Bobbie enrolled in the Franklin (white) School "every time the school was going to start in September." When asked why, she relayed a conversation she had with the superintendent of the Santa Ana School District:

$[\mathrm{H}] \mathrm{e}$ asked why was it that I wanted Bobbie to go to the Franklin School. I told him that in the Franklin School he had more privileges, he would learn more, and he would not be held behind, kept behind in his school. ${ }^{43}$

Fuentes's repeated attempts to have her son transferred were founded on the belief that he would be better educated at the white school.

Mabel Mendez, a mother from Santa Ana, also attested to the inferior quality of education at the Mexican schools. In regard to a letter she received from the Santa Ana School Board instructing her to enroll her child in the Freemont (Mexican) School, the court inquired, "What was there about the letter that caused you to be concerned?" Mabel Mendez replied:

I didn't want my little boy to go to the Freemont . . . because he is well-advanced at the Franklin, and he has always attended that, and knowing they don't progress very much at the Freemont, I didn't want him to go back on his grades. ${ }^{44}$ 
Mabel Mendez's words, much like those of Felicitas Fuentes, speak to the harsh disparities between the Mexican and white schools. Nowhere in the testimonies of these women do they argue per se in support of school integration. Rather, their arguments are grounded in notions of equality, hence marking Mendez as a civil rights matter. Under the mandate of Plessy v. Ferguson (1896), all parties agreed that de jure segregation existed: this remained undisputed by lawyers on both sides of the legal debate. Thus, the legality of segregation was not under scrutiny, but rather the idea of "separate but equal." That is to say, if "separate" was so agreed upon, as it was in Mendez, then what of "but equal"? This seemed to be the question before the courts and that posed by women like Felicitas Fuentes and Mabel Mendez.

The testimonies of these mothers reflect that the battle over desegregation had less to do with integrating their children with whites and more to do with the attainment of what white children had: access to better schools. Rendered as such, a distinction can be drawn between school integration and racial inequality. Such a distinction is important in getting at what caused women like Felicitas Fuentes and Mabel Mendez to act and lend their support to a class action lawsuit such as the Mendez case. In light of the fact that the plaintiffs grounded much of their argument in notions of equality, the practice of segregating students was posited by the plaintiffs' attorneys to be a violation of Mexican American children's constitutional rights. Having found the defendants to be in violation of the students' Fourteenth Amendment Rights, the Court concluded that by separating Mexican children from whites, the defendants were in fact "depriving them of liberty and property without due process of the law." ${ }^{45}$ For Felicitas Fuentes, the distinction between civil rights and school integration must have been particularly painful. As previously noted, she had one son, Joe, fighting to defend democracy in the war and another son, Bobbie, denied his civil rights at school.

Similar to Felicitas Fuentes and others, Virginia Guzman also looked to protect her son from racial inequality by requesting a school transfer. Unable to successfully secure one, Virginia Guzman took what could be perceived as drastic measures: she opted to keep her son home. She explained:

I kept him home. When they didn't want to admit him to that school that was near our house, and they wanted me to send him to Freemont School, which was an all-Mexican school, I said, 'No! He's not going! He's not going! I'm gonna keep him home." 46

Virginia's comments reflect the strong sentiment held by many Mexican parents at the time. In response to the districts' segregation policies, several families involved in the lawsuit elected to enroll their children in private schools or postponed enrolling them in school altogether. 
The delaying of their children's education reflects not only the resourcefulness of these parents, if not their outright desperation, but also their level of indignation. For many, including Virginia Guzman, the mere thought of separate schools for Mexicans was offensive. She argued, "Did they think they were better than us or what? That was my son. My son! I couldn't send him there [the Mexican school]!” Thus, rather than subject her son to a discriminatory school system, she opted out of the system altogether. In contrast to the other parents, however, Virginia Guzman's refusal to enroll her son in a segregated all-Mexican school went beyond mere indignation and was rooted in her own childhood experiences as a student.

As a child, Virginia Guzman attended a segregated school herself. In fact, she attended the same Mexican school her son Billy was ordered to attend some fifteen years later. Born and raised in Santa Ana, Virginia lived in the district's Mexican zone and thus attended the Freemont (Mexican) school. While attending the Mexican school, she personally experienced the transgressions of a racialized school system. Vividly recalling the harsh treatment she and her classmates endured, Virginia explained that "Mrs. Gilbert, the principal, she had a special room, a rubber hose and les pegaba (she would hit them).... She didn't want us speaking Spanish." The violence inflicted on students in Mexican schools was a practice cited by a number of participants involved in this study, yet it was erroneously overlooked in the legal documents related to the case. Such findings highlight not only the significance of Counterstory-telling as a research method but also the importance of giving voice to those who have been silenced by "official" accounts. Many of the students interviewed for this study recalled being physically reprimanded for their use of Spanish on school grounds and/or ridiculed or humiliated by students and teachers alike. For many reasons, theirs is an important story to tell. It serves not only to inform questions regarding the motives of women involved in the Mendez case but also to illustrate the kind of disdain directed at Mexican American children at the time. Evidence of this is located in the story of Catalina Vasquez, a former student of the Hoover (Mexican) School in Westminster. In an interview for this study, Catalina recalled how the teacher of her class would often hit female students:
She'd pull our dress up and make sure all the class was there and spank you on the bottom ... or else with a ruler on our knuckles. ... I remember her as being a good one for hitting everybody on the knuckles for any little thing. ... She was famous for that. ${ }^{47}$

Interestingly enough, Catalina's response to the violence she experienced prompted her to resist integration. As an upper-grade student [Figure 4], she graduated while the case was still in litigation, thus avoiding desegregation. Recalling her reaction to the court's ruling, Catalina expressed her relief at not having to attend a "mixed" school. She said, "I really didn't want to go. I just 


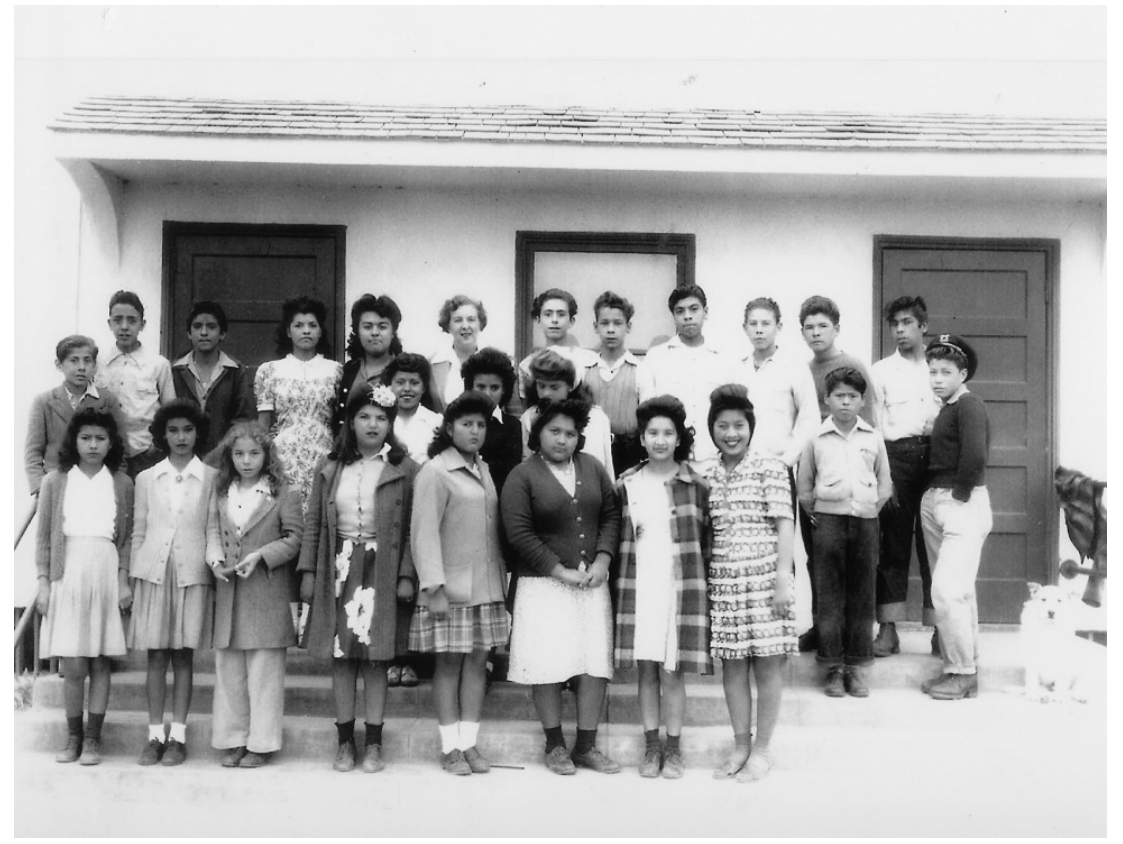

Figure 4: Mrs. Stacy's 7th and 8th Grade Class, Hoover (Mexican) School, Westminster, California, 1944. Catalina (Ramirez) Vasquez (bottom row, first from the right). Courtesy of Catalina Vasquez (Ramirez).

didn't. . . . I think it was in part because of the way they [white students] behaved with us." When asked to elaborate, Catalina cited teasing, humiliation, and even violence, adding that "but they'd pay later ... we would wait for them on the Boulevard," thus suggesting retaliation. Such comments reflect the actions and motives of some involved in desegregation efforts and/or the Mendez case. While many may have been motivated by the lack of equality between the Mexican and white schools, others acted out of concern for their and their children's safety. Based on their personal experiences in the Mexican schools, women like Catalina Vasquez and Virginia Guzman resisted in whatever capacity they saw fit, as did many others.

Located in the data is a barrage of stories about the strategies employed by those looking to avoid school segregation. Some recalled school officials being "paid off" in order to ensure their child a school transfer. Others reported falsifying their home addresses so that their children could attend the better white schools. ${ }^{48}$ Still others circulated petitions, attended board meetings, and organized the community, while some, like those involved in the Mendez case, filed a lawsuit. Moreover, the students themselves resisted. Though little has been written about the manner in which children of Mexican descent resisted institutionalized racial discrimination, they did in fact resist. Some recalled speaking 
Spanish just to "spite the teachers." Still others returned violence with violence, as in the case of Catalina Vasquez. And some, like Carol Torres, a student in the El Modena School District, took a more transformative approach. ${ }^{49}$ In an effort to address the district's separatist practices, she organized meetings with students and administrators. As explained by Carol as a witness for the plaintiffs, and later confirmed in an interview for this study:

We wanted to know why we were separated, the American people, the American children and the Mexican children. We were all American citizens, and we didn't see why they had us separated.

Of particular interest in Carol Torres's case was the proximity between the Mexican school she attended and the neighboring white school. As depicted in Figure 5, the two schools shared the same grounds but were separated by a baseball diamond [Figure 5]. Despite the proximity of the two schools, school officials ensured the separation of Mexicans and whites through the establishment of various school policies and practices, including the scheduling of student activities at staggered times. When asked about such practices, Carol responded, "We told him [school principal] we didn't like that, because pupils of Mexican descent went over to Roosevelt [white] School and they [the students] considered themselves superior to us." ${ }^{50}$ Supporting Carol's assessment is a study by historian Martha Menchaca, who posited that "One of the main reasons school segregation was institutionalized was to ensure that racial minority groups would not come into contact with Anglo Americans." ${ }^{51}$ The notion that

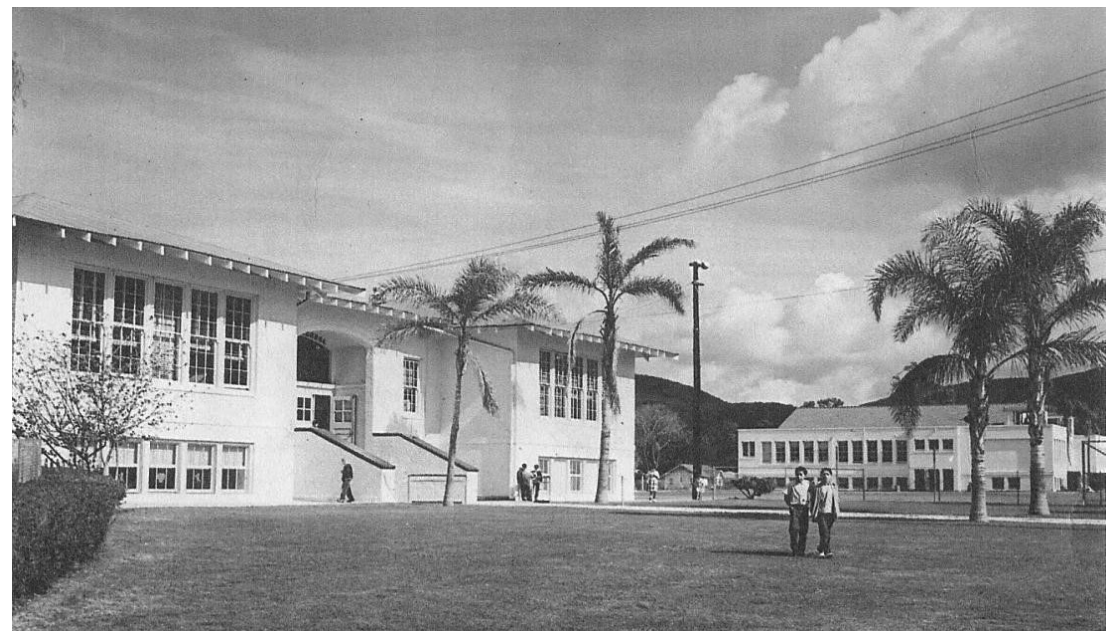

Figure 5: Fremont School (Left) and Franklin School (Right), El Modena School District, El Modena, California, 1940s. Courtesy of Teresa Ramirez and the Ramirez Family. 
students at the white school "considered themselves superior" to Mexican students points to the underlining premise informing segregation: notions of white superiority. As supported by Bell in his study of the Brown case, "The purpose of these policies was not simply to exclude or segregate but to subordinate those who, based on their color ... were presumed to be inferior to Whites." ${ }^{25}$ While legal counsel looked to sidestep this topic, students like Carol Torres tackled it head on. As one directly impacted by such practices, Carol's assessment of school segregation speaks to notions of white supremacy and the harmful effects it had on students in Mexican schools. Virginia Guzman's experiences, as both a student and a parent, support these notions.

As previously noted, Virginia attended a Mexican school as a child. As a parent, she was ordered to send her son to the same school she attended, which she steadfastly refused to do. Virginia's outright defiance of school authorities underscores the significance of women to the case and the level of agency they brought to the desegregation battle. Though largely overlooked in the existing literature, she also testified in court, attended district meetings, organized parents, fundraised, circulated petitions, and along with her husband, William Guzman, hired an attorney.

The actions exhibited by Virginia Guzman and the other women highlighted in this paper are twofold: first, they wanted their children to get a better education than that available to them at the Mexican schools; and second, they wanted to protect their children from institutionalized racial discrimination. Acting in their children's best interest, these women engaged in activism that was partially grounded in their identity as Americans and, as previously indicated, partially in their identity as mothers. Much like the "Mothers of East L.A." (MELA), a group of mothers in East Los Angeles who organized to protect their children from environmental racism, the "Mothers of Mendez" organized to protect their children from a racist school system. In her study of MELA, social scientist and Chicana scholar Mary Pardo delineated the connection between political activism and ideals of motherhood. As determined by Pardo, "the name of the organization, 'Mothers of East Los Angeles,' clearly communicates gender identity and the metaphor of mother as protector of the community." 53 Pardo's synopses of "mother as protector" and the link between motherhood and activism is similarly located in a study of Mendez.

Well-documented in the court transcripts are numerous references to the status of women as mothers. For example, during the trial, Felicitas Fuentes testified that she and "a lot of the other mothers" had gone repeatedly to talk with board members about sending their children to the white schools. In another example, Manuela Ochoa, one of the "other mothers" and witnesses for the plaintiffs, testified to the inferior education her children received and the numerous conversations she had with district authorities about it. She petitioned for school transfers; conversed with teachers, principals, and superintendents; and even consulted with the Child Welfare Office. Manuela proved to be a crucial witness for the plaintiffs and a primary actor in the desegregation battle. 
Able to draw from the experiential knowledge she possessed, Manuela Ochoa attested to the arbitrary enforcement of school zones, the discretionary granting of school transfers, the racism inflicted on Mexican origin children, and the substandard quality of education in "Mexican schools." Indeed, Manuela's contributions to the case are evident at its every junction. In fact, the data clearly show that she met with school officials as early as 1939 , five years prior to the official filing of Mendez et al. v. Westminster et al. This speaks directly to the grassroots efforts of those involved and the significance of women to the case. Without the contributions of Manuela Ochoa and the countless other women who participated, it is reasonable to surmise that attorneys for the plaintiffs would have been hard-pressed to make their case.

For the many women involved in the Mendez case, their opposition to school segregation went beyond opposing the practice of separating Mexican students from whites and was rooted in ideals of social equality. In hopes of securing their children and generations of children the brightest future possible, these women wrapped their objections in notions of equality and their faith in the "American dream." Perhaps this contention is best expressed in the words of Virginia Guzman. Recollecting her involvement in the case and her childhood experiences in the Mexican school, Mrs. Guzman tearfully stated,

\begin{abstract}
Habia [there was] so much discrimination. . . . If I would have had a chance. If I would have gone to Franklin or the other [white] schools, maybe I would have gotten more. All I needed was a chance! ${ }^{54}$
\end{abstract}

Mrs. Guzman's plea for a "chance" speaks to the motives of many involved in the Mendez case. Although several plaintiffs attended the same schools as their children, including Gonzalo Mendez and Lorenzo Ramirez, they did so prior to the schools' being officially designated as segregated. Understandably, these parents were outraged by the thought of their children being refused admittance to the very same schools they themselves had attended. Unique to Virginia Guzman, however, was the fact that she attended the school her son was ordered to attend at a time after it was officially deemed a "Mexican school." In his study of the Santa Ana School District, Stromberg reported that by the 1920s the district had three Mexican schools in place: Logan, Delhi, and Freemont. ${ }^{55}$ Twenty years later, at the time the Mendez case went to trial, all three schools were identified as being " $100 \%$ Mexican." Having attended a segregated school herself, Virginia Guzman understood the glaring disparities between white and Mexican schools, noting that "The white schools were better." She also understood well the prejudicial attitudes commonly held toward Mexican students: "They didn't care porque somos Mexicanos [because we were Mexicans]." Afraid for her son's well-being and based on her educational experiences, Virginia recalled: 
That's why I didn't want my son to go there [the Freemont (Mexican) school]. I wanted my son to get a better education than what I got there. I knew what was going on, and I knew what I went through, so I said "No!" 56

Virginia's refusal to send her son to a segregated school speaks to women's agency and the manner in which they resisted. When asked to elaborate, she stated, "I wanted him to get a good education, hablando [speaking] English. Porque si saben, sí crecen bien y todo está bien [Because if you know it, if you're raised fine and everything's fine]." Remarks like these reflect the general attitudes held by many involved in the Mendez case. In hopes of protecting their children from racial discrimination and ensuring them the best education possible, they eagerly engaged in American customs such as speaking English and wholeheartedly believed in American ideals like democracy.

\section{Conclusion}

Important to a gender analysis of Mendez et al. v. Westminster et al. is an understanding of the sociopolitical context in which it emerged. In the midst of World War II, women of Mexican ancestry worked to defend democracy from enemies afar. And in the era of Jim Crow, they struggled to ensure it for those they loved. What does it mean to be an American under these conditions?

Freire tells us that for a people to be truly free, they must learn to read the world. Clearly, the women involved in the Mendez case read the world. In the age of de jure segregation, they read the world and came to the conclusion that in many ways it was unjust. It was unjust because it denied their children their constitutional rights. It was unjust that they were subject to racial discrimination. And it was unjust that they were denied a quality education. Thus, the women of Mendez read the world and in so doing, found their voice and the will to act. They organized on behalf of their loved ones, questioned the social norms that painted them inferior, and pushed back at the racial injustices impeding their lives. In short, they resisted. It is in this resistance where knowledge resides. It is where the lessons of Mendez are to be found, and where we - the descendants of desegregated schooling - have an obligation to tell their story and continue their fight. Mendez et al. v. Westminster et al. is more than the sum of its parts; it is an obligation - not solely to those who lived it, but more importantly, to the generations who succeed it. Be it de jure or de facto - segregation exists, and countless students remain hanging in the balance. How are we as a nation to reckon with this, and what lessons can be learned from a study of Mendez? If the women of Mendez read the world today, what might they think, and how might they resist? As an educator, woman, Chicana, and a Bermudez, these are the questions I ponder and feel obliged to address.

The Mendez case is a part of me. It is in my blood, spirit, gender, race, and profession and will forever remain in my consciousness. I make no apologies 
for this, not as a researcher or a scholar. It is how I read the world. The findings of this study suggest that the agency of women involved in desegregation efforts stemmed in part from the naming that defined them. It is this same naming that compelled me to tell their story.

This telling of the Mendez case is intended to impact scholarship that values the experiential knowledge of those on the margins. Largely overlooked, if not erased by conventional wisdom, are the contributions of women like those involved in the Mendez case. This study of Mendez et al. v. Westminster et al. is intended to honor their memory, tell their story, and reinscribe their place in history.

\section{Notes}

1. As described in the legal documents.

2. With the exception of Felicitas Mendez, the women involved in the Mendez case were of Mexican ancestry.

3. C.G., personal communication, July 14, 2003.

4. Other researchers have cited similar stories in their studies of school segregation, e.g., Derrick Bell, bell hooks, Ladson-Billings, and Charles M. Wollenberg.

5. It should be noted that these research methods were also selected because of their critique of objectivity and the role of the researcher as a casual observer.

6. Daniel G. Solorzano and Tarra J. Yosso, "Critical Race Methodology: Counter-storytelling as an Analytical Framework for Educational Research," Qualitative Inquiry 8, no. 1 (2002): 23-44. 2000).

7. bell hooks, Feminist Theory: From Margin to Center (Cambridge, MA: South End Press,

8. Teresa Cordova, "Power and Knowledge: Colonialism in the Academy," in Living Chicana Theory, ed. C. Trujillo (Berkeley: Third Women Press, 1998), 38.

9. See Maylei Blackwell, Chicana Power! Contested Histories of Feminism in the Chicano Movement (Austin: University of Texas Press, 2011); Cordova, "Power and Knowledge"; Martha Menchaca, Recovering History, Constructing Race: The Indian, Black, and White Roots of Mexican Americans (Austin: University of Texas Press, 2001); and Emma Perez, The Decolonial Imaginary: Writing Chicanas into History (Bloomington, Indiana: Indiana University Press, 1999).

10. Most notably, a commemorative stamp was issued by the federal government to honor the Mendez case in 2007, and Sylvia Mendez was awarded the Medal of Freedom by President Obama in 2010. While these accolades are grand, it should be noted that the Mendez case has yet to be included in curricula, history books, and those spaces in which knowledge is produced and legitimized.

11. The first names of the women involved in this study are used to distinguish them and their actions from those of their husbands.

12. See Christopher Arriola, "Knocking on the Schoolhouse Door: Mendez v. Westminster, Equal Protection, Public Education, and Mexican Americans in the 1940s," La Raza Journal 8, no. 2 (1995): 166; Gilbert Gonzalez, Chicano Education in the Era of Segregation (PENN: The Balch Institute Press, 1990); Sandra Robbie, Para Todos los Ninos/For All the Children, directed by Sandra Robbie (2003), film.

13. Emma Perez, The Decolonial Imaginary, 7.

14. See Jennifer Ayala and Cesar J. McCormick, "Felicita 'La Prieta' Mendez (1916-1998) and the End of Latino School Segregation in California in Centro," Journal of the Center for Puerto Rican Studies 19, (2007): 13-35; Philippa Strum, Mendez v. Westminster: School Desegregation and Mexican-American Rights (Lawrence, KS: University Press of Kansas, 2010).

15. See Blackwell, Chicana Power!; Cordova, "Power and Knowledge"; Menchaca, Recovering History; and Perez, The Decolonial Imaginary.

16. Cherrie L. Moraga and Gloria Anzaldua, This Bridge Called My Back: Writing by Radical Women of Color (New York: Kitchen Table: Women of Color Press, 1983). Out of respect for the author, I maintained the formatting and spacing of her writing.

17. Moraga and Anzaldua, ibid.

18. In an attempt to avoid essentializing their experiences, the stories they shared were triangulated, when possible, with the court documents, existing literature and/or stories of other participants. 
19. Mendez et al. v. Westminster et al., 64 F. Supp. 544 (S.D. Cal. 1946).

20. Virginia Guzman, personal communication, July 9, 2005.

21. "Double consciousness" refers to the internal conflicts often experienced by subordinate groups based on conflicting identities, see W. E. B. Du Bois, The Souls of Black Folk (Auchel, NJ: Gramercy Books, 1994).

22. Richard Griswold del Castillo, World War II and Mexican American Civil Rights (Austin, Texas: University of Texas Press, 2008), 57.

23. Ibid., 57.

24. Ibid., 62.

25. Mendez v. Westminster, 1946.

26. Rodolfo Acuña, Occupied America: A History of Chicanos, 5th edition (New York: HarperCollins, 2004), 241.

27. Mendez v. Westminster, 1946.

28. Griswold del Castillo, World War II and Mexican American Civil Rights, 62.

29. Ysaura Bermudez, personal communication, June 24, 2003.

30. Griswold del Castillo, World War II and Mexican American Civil Rights, 197.

31. Attorneys for the defendants labeled the actions of some plaintiffs as undemocratic based on the argument that some failed to follow school protocol.

32. It may also reflect notions of respect within the Mexican culture toward people in positions of power and for the law itself.

33. Mrs. Ramirez spoke Spanish, and as such the interview was conducted in Spanish. To preserve her words, and to protect the integrity of the interview, I have included the Spanish version here with the English translation.

34. Josefina Ramirez, personal communication, March 24, 2005.

35. Patricia Hill Collins, Black Feminist Thought: Knowledge, Consciousness, and the Politics of Empowerment (New York: Routledge, 2009), 198.

36. Ibid.

37. Ibid., 123.

38. Ibid., 200.

39. Ibid., 199.

40. Daniel G. Solorzano and Dolores Delgado Bernal, "Critical Race Theory, Transformational Resistance, and Social Justice: Chicana and Chicano Students in the Urban Context," Urban Education, 36 (2001): 308-342. Solorzano and Delgado Bernal assert that there are four types of resistance in which students sometimes engage 1) reactionary behavior, 2) self-defeating resistance, 3) conformist resistance, and 4) transformational resistance. According to Solorzano and Delgado Bernal, transformative resistance reflects the actions of students who express "both a critique of oppression and a desire for social justice" (7).

41. See, for example, Dred Scott v. Sandford, 1857; Calhoun v. Cook, 1973; and Milliken v. Bradley, 1974.

42. Derrick Bell, Silent Covenants: Brown v. Board of Education and the Unfulfilled Hopes for Racial Reform (New York: Oxford University Press, 2004), 115.

43. Mendez v. Westminster, 1946.

44. Ibid.

45. Ibid.

46. Virginia Guzman, personal communication, July 9, 2005.

47. Catalina Vasquez, personal communication, May 5, 2004.

48. Gonzalez, Chicano Education.

49. As previously noted, Solorzano and Delgado Bernal assert that there are four types of resistance in which students sometimes engaged.

50. Mendez v. Westminster, 1946.

51. Martha Menchaca, The Mexican Outsiders: A Community History of Marginalization and Discrimination in California (Austin: University of Texas Press, 1995), 59.

52. Bell, Silent Covenants, 12.

53. Mary Pardo, Mexican American Women Activists: Identity and Resistance in Two Los Angeles Communities (Philadelphia: Temple University Press, 1998), 144.

54. Virginia Guzman, personal communication, August 15, 2005.

55. Robert Stromberg, An Historical Study of the Santa Ana Unified School District, 1869 to 1969 (master's thesis, California State College, Fullerton, 1970).

56. Virginia Guzman, personal communication, August 15, 2005. 